\title{
Pilot Plant Scale Manufacture of Bread Enriched with Seed Protein Concentrates
}

\author{
Özgenur Coşkun ${ }^{1,2, a}$, Halime Pehlivanoğlü,b, İbrahim Gülseren ${ }^{1,4, c, *}$ \\ ${ }^{I}$ Department of Food Engineering, İstanbul S. Zaim University (İZ̈̈), Halkalı Campus, 34303 Küçükçekmece, İstanbul, Turkey \\ ${ }^{2}$ Department of Food Science, Aarhus University, Denmark \\ ${ }^{3}$ Department of Food Hygiene and Technology, Faculty of Veterinary Sciences, Namık Kemal University (NKÜ),59030 Tekirdağ, Turkey \\ ${ }^{4} \dot{I Z U ̈ U}$ Food and Agricultural Research Center (GTAUM), Küçükçekmece, Istanbul, Turkey
}

${ }^{*}$ Corresponding author

\begin{tabular}{|c|c|}
\hline ARTICLE INFO & A B S T R A C T \\
\hline $\begin{array}{l}\text { Received : 28/09/2020 } \\
\text { Accepted : 17/05/2021 }\end{array}$ & $\begin{array}{l}\text { For many seeds, cold press technology generates higher quantities of cakes than seed oils, which are } \\
\text { concentrated in proteins. Valorization of the cakes could offer a viable strategy to manufacture protein } \\
\text { fortified foods with comparable characteristics as the conventional products. Here, black cumin, grape } \\
\text { seed and pumpkin seed protein concentrates were prepared based on an alkaline extraction-isoelectric } \\
\text { precipitation technique. The influence of protein concentrate addition on the flour, dough and bread } \\
\text { characteristics were investigated for textural profile, gluten quality and visual characteristics } \\
\text { including color attributes. While the interactions between gluten and seed proteins were mostly weak, } \\
\text { some of the physicochemical attributes differed significantly. In terms of volume and visual } \\
\text { characteristics, pumpkin seed protein concentrates enriched bread demonstrated similar } \\
\text { characteristics as the controls, while black cumin or grape seed protein concentrate enriched wheat } \\
\text { flours were more resistant and less extensible than the controls. Similarities and differences between } \\
\text { controls and protein enriched gluten-free or gluten-bearing bread were discussed. }\end{array}$ \\
\hline
\end{tabular}

Grape seed

Pumpkin seed

Protein fortification

Türk Tarım - Gıda Bilim ve Teknoloji Dergisi, 9(6): 991-997, 2021

\section{Tohum Protein Konsantrelerince Zenginleştirmiş Pilot Tesis Ölçekli Ekmek Üretimi}

\begin{tabular}{|c|c|}
\hline M A K A L E B İ L G İ S İ & $\dot{0} \mathrm{Z}$ \\
\hline $\begin{array}{l}\text { Anahtar Kelimeler: } \\
\text { Soğuk pres posas } 1 \\
\text { Çörek otu } \\
\text { Üzzüm çekirdeği } \\
\text { Kabak çekirdeği } \\
\text { Proteince zenginleștirme }\end{array}$ & $\begin{array}{l}\text { Birçok tohumun soğuk pres teknolojisi ile işlenmesi sürecinde, üretilen yağdan daha fazla miktarlarda } \\
\text { proteince zengin posa (pres kekleri) açığa çıkmaktadır. Posanın değerlendirilmesi, proteince } \\
\text { zenginleştirilmiş ve diğer özellikleri konvansiyonel ürünlere benzeyen gidaların üretilmesi için uygun } \\
\text { bir strateji sunmaktadır. Bu çalışmada çörek otu, üzüm çekirdeği ve kabak çekirdeği protein } \\
\text { konsantreleri alkali ekstraksiyon-izoelektrik çökeltme tekniğine uygun olarak üretilmiştir. Protein } \\
\text { konsantresi eklemenin un, hamur ve ekmek özelliklerine etkisi tekstür profili, gluten kalitesi ve renk } \\
\text { özelliklerini de içermek üzere görsel özellikler açısından incelenmiştir. Gluten ve tohum proteinleri } \\
\text { arasındaki etkileşimler çoğunlukla zayıfken, bazı fizikokimyasal özelliklerin değiştiği bulgulanmıştır. } \\
\text { Hacim ve görsel özellikler açısından, kabak çekirdeği protein konsantresi ile zenginleştirilmiş ekmek, } \\
\text { kontrol grubu ile benzer özellikler gösterirken, çörek otu veya üzüm çekirdeği protein konsantresi ile } \\
\text { zenginleştirilmiş buğday unları, kontrollere göre daha fazla direnç gösterdikleri ve daha düşük } \\
\text { uzayabilirlik değerlerine sahip oldukları bulunmuştur. Kontroller ve proteinle zenginleştirilmiş } \\
\text { glutensiz veya gluten içeren ekmekler arasındaki benzerlikler ve farklılıklar tartış1lmıştır. }\end{array}$ \\
\hline
\end{tabular}




\section{Introduction}

Bread is a staple food that is consumed globally and most often, wheat is utilized in its production. In most industrial bread formulations, bran is removed from the wheat flour due to ease of processing, while wheat flour becomes poorer in terms of essential amino acids (Delcour and Hoseney, 2010). Consequently, protein enrichment of bread is an active area of research (Stelten et al., 2014). Proteins could enhance technical attributes of processed foods including textural and flavor related characteristics as well as its storage stability. Protein based ingredients will especially be practical, when they can be directly incorporated into the formulations, for example using their powdered forms (Storck et al., 2013).

Press meals or cakes are among the primary byproducts of vegetable oil processing. Especially in the context of cold press technology, considerable quantities of cakes form. In many cases, such by-product streams (i.e., press cakes) are characterized by their technically and biologically functional molecule content and their valorization could lead approximately to zero waste and sustainable, circular economic strategies (Drozłowska et al., 2020). Most seeds have significant concentrations of protein prior to processing. Removal of seed oil further concentrates the protein molecules in the cakes. Consequently, valorization of press cakes seems to be a viable strategy in the manufacture of protein fortified food products (Coşkun et al., 2020).

Black cumin (BC) (Nigella sativa) is a valuable and annually flowering medicinal plant from Ranunculaceae family that is native to the Eastern Mediterranean countries, Southern Europe and Asia Minor (Baydar, 2009; Baytop, 1999). Black cumin seeds contain approx. $21 \%$ protein, whereas its corresponding cold press cake could easily account for $>30 \%$ protein (Coşkun et al., 2019). Previously pumpkin seed ingredients including pumpkin seed (PS) proteins have been utilized in both food formulations and nutritional supplements thanks to their health-promotion potential (Bucko et al., 2015; ElSoukkary, 2001). Based on simple aqueous extraction techniques, it is possible to generate pumpkin seed protein concentrates with high protein content $(>80 \%)$ (Coşkun and Gülseren, 2020). Grape (Vitis vinifera L.) seeds (GS) constitute another abundant source of seed protein, since approx. 69 million tons per year of grapes are produced globally (FAOSTAT, 2011). The seeds account for approximately $2-3 \%$ of the harvest and the protein content in the seeds is approx. 10-13\% (Fantozzi, 1981).

While valorization of cold press cakes could offer a viable strategy to manufacture protein fortified bread, the characteristics of the final products must be comparable to that of the conventional products in terms of textural profile, gluten quality and visual characteristics among other attributes.

Farinograph and extensograph measurements are generally used to determine the bread making properties of bread flour and structural attributes of the dough. Farinograph analysis yields information about the characteristics of kneading dough and baking bread. The ability of the dough to retain carbon dioxide during fermentation is related to extensibility and resistance to extension parameters measured in farinographic analysis, which in turn, are important for bread making properties of the flour. Extensograms yield information about the overall quality of the flour and its response to additives (Delcour and Hoseney, 2010). For example, Ziobro et al. (2013) previously reported about the strong influence of plant protein additives on dough properties.

In our previous studies, cold press cakes of BC, PS and GS were utilized in the manufacture of gluten-free bread formulations (Coşkun et al., 2020). It was found that addition of protein concentrates (PC) significantly increased firmness and decreased springiness of the crumb with the exception of pumpkin seed protein concentrate (PSPC) samples, while further water inclusion enabled the correction of the firmness attribute.

In this study, a further effort was made to valorize cold press cakes of $\mathrm{BC}, \mathrm{PS}$ and $\mathrm{GS}$ to generate protein concentrates (PC) (i.e., BCPC, PSPC and GSPC, respectively), and utilize them in protein enrichment of gluten bearing bread products. The influence of protein enrichment on the textural properties of the flour, dough and bread samples was investigated and the findings were compared to the earlier findings on gluten-free bread products regarding protein-protein and protein-water interactions. The current techniques are highly adaptable to industrial bread manufacture practices and could be exploited as a strategy to valorize vegetable oil manufacturing by-products including but not limited to that of currently analyzed seeds.

\section{Material and Methods}

\section{Materials}

Cold press cakes of black cumin, pumpkin, and grape seed meals were generously donated by Oneva (Neva Foods Ltd., İstanbul, Turkey), a local manufacturer of cold press oils. The material for dough and bread making consisted of wheat flour, salt and compressed yeast (Marmara Maya, İstanbul, Turkey) were purchased from a local store. All chemicals used were of reagent grade and purchased from Sigma-Aldrich Corp (Schnelldorf, Germany).

\section{Methods}

Preparation of Seed Protein Concentrates via Alkali Extraction-Isoelectric Precipitation Method (AE-IP)

Protein concentrate preparation technique was based on the solubilization of protein molecules at basic $\mathrm{pH}$, which was followed by the isoelectric precipitation at acidic $\mathrm{pH}$ values (Boye et al., 2010). Briefly, $50 \mathrm{~g}$ of cold press cake was dispersed in water $(1: 15, \mathrm{w} / \mathrm{v})$ and medium $\mathrm{pH}$ was adjusted to $\mathrm{pH} 9.5$ using $1.0 \mathrm{~N} \mathrm{NaOH}$. The dispersions were stirred at $500 \mathrm{rpm}$ for $1 \mathrm{~h}$ at ambient temperature $\left(22 \pm 1^{\circ} \mathrm{C}\right)$. Immediately afterwards, the dispersions were centrifuged at a rate of $4200 \times \mathrm{g}$ (Mixtasel-BL centrifuge, Spain) for $30 \mathrm{~min}$. The supernatant containing the solubilized proteins was collected and medium $\mathrm{pH}$ was adjusted to $\mathrm{pH} 4.5$ using $1.0 \mathrm{~N} \mathrm{HCl}$ to induce isoelectric precipitation. To ensure the complete separation of precipitating proteins, the supernatant was again centrifuged at $4200 \times \mathrm{g}(30 \mathrm{~min})$. The pellet was collected, frozen at $-20^{\circ} \mathrm{C}$ and lyophilized using a Teknosem TRS 
$2 / 2 \mathrm{~V}$ freeze drier. The protein contents of the samples were determined according to AOAC (2003).

\section{Bread Making}

Bread preparation and analysis were carried out based on the internal procedures of the supporting company (Polen Foods, İstanbul, Turkey). The composition of each and every bread recipe was listed on Table 1. For bread production, $430 \mathrm{~g}$ water, $200 \mathrm{~g}$ ice, $1000 \mathrm{~g}$ wheat flour, 15 $\mathrm{g}$ salt and $25 \mathrm{~g}$ compressed yeast were used. The protein content was enhanced by $1.5 \%(\mathrm{w} / \mathrm{w})$ in all cases. Firstly, all ingredients except salt and yeast were added to the mixing vessel (DIOSNA - Dierks \& Söhne GmbH, D49074, Germany) and mixed for 4 minutes. Then other ingredients were added to the mixing vessel and bread dough was made. The doughs were rolled and shaped (Ekmasan EK-37, Turkey) and fermentation was carried out using a Juniorlev cabinet (Tecnomac, Italy) for 3 different fermentation durations $(80,110$, or $140 \mathrm{~min})$. In this context, a total of 4 different types of bread utilizing 3 different protein concentrates and a control sample and 3 different fermentation times were studied. Baking was carried out for $30 \mathrm{~min}$ using an industrial oven (Wiesheu Wolfen GmbH, Germany). The bottom and top were baked at $220^{\circ} \mathrm{C}$ and $230^{\circ} \mathrm{C}$, respectively. Once baking was complete, the samples were removed from the oven, and cooled at ambient temperature $\left(21^{\circ} \mathrm{C} \pm 1\right)$.

Wheat Flour Analysis

Falling number (ICC method (1995) using Perten, 1500, Sweden), fungal falling number (Perten, FN 1900, 1995), sedimentation, delayed sedimentation (ICC method 116/1, 40 cycle/minutes, Erkaya, Zeleny 120, Turkey), wet gluten and gluten index (ICC method 137-1 (2000) using Perten GM 2200, Sweden) of control wheat flour and wheat flour enriched with protein concentrates were determined based on the listed methods (ICC, 1995, 2000, 2018; Perten, 1995).

\section{Determination of Dough Rheology}

Rheological properties of dough samples were based on farinograph and extensograph measurements. Farinograph analysis was based on AACCI method 54.21 using Brabender Farinograph-E 810114, whereas extensograph analysis utilized AACCI method 54.10 using Brabender Extensograph-E 860702, Germany (AACCI, 2000a, b).

Texture Profile Analysis

Texture profile analysis (TPA) of bread crumbs was performed using TA-XT2plus texture analyzer (Stable Micro Systems, England), according to standard program, at the test speed rate $1 \mathrm{~mm} / \mathrm{s}$. Bread crumb sample, taken from the center of the loaf with a height of $2 \mathrm{~cm}$ was pressed to reach $25 \%$ strain by a P/236 R (AACC $36 \mathrm{~mm}$ cylinder probe) for $60 \mathrm{~s}$. The resulting firmness and springiness of the crumb were used as indicators of textural changes. The calculations were performed using Texture Exponent software (Stable Micro Systems, England). The analysis was performed $2 \mathrm{~h}$ after baking to ensure cooling of the crumb (Ziobro et al., 2013).

\section{Color Parameters}

The crumb color was determined using Hunter lab Colorflex EZ spectrophotometer (Germany). The instrument was calibrated using a white standard calibration plate and the color was expressed in CIE-Lab space as L* (whiteness/darkness), a* (redness/greenness) and b* (yellowness/blueness) (Jafari et al., 2017).

\section{Statistical Analysis}

All experimental data were analyzed by using SPSS (version 25, SPSS Inc., USA). One-way ANOVA with post hoc Tukey tests were carried out to compare groups and establish statistical significance $(\mathrm{P}<0.05)$ based on the differences in groups and between groups. Data were expressed as sample mean \pm standard deviation. In all cases, at least three replicates were analyzed.

\section{Results and Discussion}

\section{Analysis of Wheat Flour}

In all cases, solvent based extraction was avoided in order to preserve the structural and functional characteristics of protein concentrates. The protein contents of the black cumin, grape and pumpkin seed protein concentrates prepared via an AE-IP methodology were found to be approx. $54.7 \%, 30.1 \%$ and $82.9 \%$, respectively, as measured by the Kjeldahl method (AOAC, 2003). Recipes for bread making were adjusted accordingly (Table 1).

Basic characteristics of wheat flour (i.e., control sample) and seed protein enriched flour samples were investigated based on wet gluten, gluten index, sedimentation, delayed sedimentation, falling number and fungal falling number analyses. The results were summarized on Table 2. Wet gluten values of the control sample, black cumin protein concentrate (BCPC), grape seed protein concentrate (GSPC) and pumpkin seed protein concentrate (PSPC) enriched wheat flours were found to vary approx. between $25-28 \%$. In most cases, the wet gluten values did not indicate statistically significant differences compared to the controls. The values for the control sample were comparable to the earlier findings on gluten isolated from Indian wet cultivars (Singh and Singh, 2006). Similarly, gluten index measurements indicated that the inclusion of seed proteins did not significantly affect the index value, possibly since gluten content did not change and the influence of the protein concentrate addition was relatively low. Gluten index values were also comparable with the previous findings (Kaushik et al., 2015). Since gluten content and/or quality did not significantly change, once again in most cases, sedimentation and delayed sedimentation values were statistically similar to that of the control sample.

Table 1. Recipes for bread products (B-BCPC: Bread enriched with black cumin protein concentrate; BGSPC: Bread enriched with grape seed protein concentrate; B-PSPC: Bread enriched with pumpkin seed protein concentrate). BCPC: black cumin protein concentrate; GSPC: grape seed protein concentrate; PSPC: pumpkin seed protein concentrate).

\begin{tabular}{|c|c|c|c|c|}
\hline Ingredient & Control & B-BCPC & B-GSPC & B-PSPC \\
\hline$\overline{\text { Water }}$ & $430.0 \mathrm{~g}$ & $430.0 \mathrm{~g}$ & $430.0 \mathrm{~g}$ & $430.0 \mathrm{~g}$ \\
\hline Ice & $200.0 \mathrm{~g}$ & $200.0 \mathrm{~g}$ & $200.0 \mathrm{~g}$ & $200.0 \mathrm{~g}$ \\
\hline Wheat flour & $1000.0 \mathrm{~g}$ & $1000.0 \mathrm{~g}$ & $1000.0 \mathrm{~g}$ & $1000.0 \mathrm{~g}$ \\
\hline Salt & $15.0 \mathrm{~g}$ & $15.0 \mathrm{~g}$ & $15.0 \mathrm{~g}$ & $15.0 \mathrm{~g}$ \\
\hline Compressed yeast & $25.0 \mathrm{~g}$ & $25.0 \mathrm{~g}$ & $25.0 \mathrm{~g}$ & $25.0 \mathrm{~g}$ \\
\hline $\mathrm{BCPC}$ & & $27.4 \mathrm{~g}$ & & \\
\hline GSPC & . & - & $49.8 \mathrm{~g}$ & \\
\hline PSPC & . & . & - & $18.1 \mathrm{~g}$ \\
\hline
\end{tabular}


Table 2. Analytical quality parameters of protein-fortified flours. F-BCPC: Wheat flour enriched with black cumin protein concentrate; F-GSPC: Wheat flour enriched with grape seed protein concentrate; F-PSPC: Wheat flour enriched with pumpkin seed protein concentrate. One-way ANOVA with post hoc Tukey tests were carried out to compare groups and establish statistical significance $(\mathrm{P}<0.05)$. In all cases, at least three replicates were analyzed.

\begin{tabular}{l|cccccc}
\hline Samples & Wet gluten $(\%)$ & Gluten index & Sedimentation Delayed sedimentation Falling number Fungal falling number \\
\hline Control & $25.2 \pm 0.14^{\mathrm{a}}$ & $99 \pm 0.07^{\mathrm{a}}$ & $31 \pm 0.07^{\mathrm{b}}$ & $37.5 \pm 0.70^{\mathrm{a}}$ & $416.5 \pm 23^{\mathrm{a}}$ & $922 \pm 0.00^{\mathrm{a}}$ \\
F-BCPC & $24.9 \pm 0.14^{\mathrm{a}}$ & $98 \pm 2.12^{\mathrm{a}}$ & $33 \pm 0.00^{\mathrm{c}}$ & $36.5 \pm 0.70^{\mathrm{a}}$ & $399 \pm 7.1^{\mathrm{a}}$ & $913 \pm 4.94^{\mathrm{a}}$ \\
F-GSPC & $27.9 \pm 0.21^{\mathrm{b}}$ & $96 \pm 1.41^{\mathrm{a}}$ & $26 \pm 0.00^{\mathrm{a}}$ & $32.5 \pm 0.70^{\mathrm{b}}$ & $389 \pm 8.5^{\mathrm{a}}$ & $824 \pm 5.65^{\mathrm{b}}$ \\
F-PSPC & $25.1 \pm 0.07^{\mathrm{a}}$ & $98 \pm 1.41^{\mathrm{a}}$ & $31 \pm 0.00^{\mathrm{b}}$ & $37.5 \pm 0.70^{\mathrm{a}}$ & $378 \pm 5.7^{\mathrm{a}}$ & $906 \pm 7.77^{\mathrm{a}}$ \\
\hline
\end{tabular}

Table 3. Extensograph parameters of dough samples prepared from protein-fortified flours. D- BCPC: Dough prepared from black cumin protein concentrate enriched wheat flour; D-GSPC: Dough prepared from grape seed protein concentrate enriched wheat flour; D-PSPC: Dough prepared from pumpkin seed protein concentrate enriched wheat flour. One-way ANOVA with post hoc Tukey tests were carried out to compare groups and establish statistical significance $(\mathrm{P}<0.05)$. In all cases, at least three replicates were analyzed.

\begin{tabular}{l|ccccc}
\hline Dough resting time & Sample & Energy $\left(\mathrm{cm}^{2}\right)$ & Resistance to extension (BU) & Extension $(\mathrm{mm})$ & Maximum (BU) \\
\hline \multirow{4}{*}{45 minutes } & Control & $70 \pm 3.2^{\mathrm{a}}$ & $302 \pm 5.9^{\mathrm{a}}$ & $134 \pm 4.2^{\mathrm{a}}$ & $375 \pm 10.01^{\mathrm{a}}$ \\
& D-BCPC & $72 \pm 4.1^{\mathrm{a}}$ & $344 \pm 6.3^{\mathrm{b}}$ & $128 \pm 11.3^{\mathrm{b}}$ & $411 \pm 5.9^{\mathrm{b}}$ \\
& D-GSPC & $85 \pm 5.6^{\mathrm{b}}$ & $331 \pm 7.2^{\mathrm{c}}$ & $143 \pm 3.2^{\mathrm{c}}$ & $448 \pm 8.9^{\mathrm{c}}$ \\
& D-PSPC & $73 \pm 7.1^{\mathrm{a}}$ & $274 \pm 10.2^{\mathrm{d}}$ & $149 \pm 6.5^{\mathrm{d}}$ & $364 \pm 15.6^{\mathrm{d}}$ \\
\hline \multirow{5}{*}{90 minutes } & Control & $100 \pm 4.5^{\mathrm{b}}$ & $484 \pm 9.5^{\mathrm{a}}$ & $129 \pm 4.5^{\mathrm{b}}$ & $554 \pm 25.3^{\mathrm{a}}$ \\
& D-BCPC & $91 \pm 5.3^{\mathrm{a}}$ & $540 \pm 4.8^{\mathrm{b}}$ & $113 \pm 1.2^{\mathrm{a}}$ & $620 \pm 30.2^{\mathrm{b}}$ \\
& D-GSPC & $101 \pm 6.2^{\mathrm{b}}$ & $572 \pm 3.6^{\mathrm{c}}$ & $116 \pm 10.3^{\mathrm{a}}$ & $692 \pm 24.8^{\mathrm{c}}$ \\
& D-PSPC & $87 \pm 1.3^{\mathrm{a}}$ & $413 \pm 4.2^{\mathrm{d}}$ & $128 \pm 4.6^{\mathrm{b}}$ & $508 \pm 41.3^{\mathrm{d}}$ \\
\hline \multirow{5}{*}{135 minutes } & Control & $86 \pm 2.6^{\mathrm{a}}$ & $473 \pm 7.9^{\mathrm{ab}}$ & $117 \pm 5.3^{\mathrm{b}}$ & $542 \pm 12.35^{\mathrm{a}}$ \\
& D-BCPC & $100 \pm 6.1^{\mathrm{b}}$ & $544 \pm 8.1^{\mathrm{b}}$ & $121 \pm 8.2^{\mathrm{b}}$ & $637 \pm 26.3^{\mathrm{b}}$ \\
& D-GSPC & $93 \pm 3.2^{\mathrm{c}}$ & $576 \pm 11.6^{\mathrm{b}}$ & $111 \pm 9.6^{\mathrm{a}}$ & $662 \pm 45.6^{\mathrm{c}}$ \\
& D-PSPC & $78 \pm 4.7^{\mathrm{d}}$ & $389 \pm 13.9^{\mathrm{a}}$ & $127 \pm 4.6^{\mathrm{c}}$ & $476 \pm 30.2^{\mathrm{d}}$ \\
\hline
\end{tabular}

Falling number and fungal falling number measurements indicated that in most cases, a relatively higher -amylase activity was observed in the protein enriched samples, possibly due to the -amylase content of the protein concentrates (Table 2). In general, gluten related characteristics were relatively unaltered, whereas minor changes could be expected in the starch related attributes due to increased -amylase activity. Physical changes in starch or gluten characteristics of dough samples were recently shown to affect their gelatinization behavior (Paulik et al., 2019). While the interactions between gluten and seed proteins were weak in the current samples, some of the physicochemical attributes could still be altered by seed protein addition due to the presence of nonprotein impurities in the concentrates.

The composition of the seeds investigated here are characterized by considerably high concentrations of protein and carbohydrates. In black cumin seeds, crude carbohydrate and protein content correspond to approximately 37 and 20\%, respectively (Nergiz and Ötleş, 1993). Black cumin water soluble polysaccharides were found to be primarily composed of galacturonic and glucuronic acids as well as neutral sugar groups, while their molecular weight corresponded roughly to $800 \mathrm{kDa}$ (Trigui et al., 2018). Based on these findings, polysaccharides in BC seeds are considerably larger in molecular size compared to the BC proteins (Coşkun et al., 2019) which in turn could affect the interactions between water and protein molecules. In the grape seeds, carbohydrate concentration was considerably higher than protein content (i.e., $37 \%$ to $8.2 \%$ ) (Kamel et al., 1985). However, in the case of pumpkin kernels or pumpkin seeds, protein content was considerably higher compared to carbohydrates (i.e., approx. 4 to 1 )
(Quanhong and Caili, 2005). The extent of water-soluble polysaccharides in pumpkin seeds was also considerably lower (1.1\%) (Samant and Rege, 1989) which potentially limits their influence on the technical attributes of the PSPC. Consequently, the composition of protein concentrates and impurities present therein can be anticipated to be significantly different. The protein concentrates manufacture technique used here (AE-IP) is based on aqueous solubility. The fiber and ash components remaining in the cold press cakes can be transferred to the protein concentrates, which in turn influence the gluten and starch characteristics in the flour mix. Especially the high carbohydrate concentration in grape seeds makes it difficult to extract seed proteins and significantly affects technical attributes of the protein concentrates (Coşkun et al., 2020).

\section{Determination of Dough Rheology}

Strong flour mixtures are characterized by higher gluten quality and extensibility, enhanced bread loaf volume and height, while longer mixing durations enable homogeneous mixing of strong mixtures (Zaidel et al., 2010). Energy values also represent the resistance against the deformation and correlates well with the gas retention capacity of dough. Since the yardstick for the current treatments is the control dough, the extensograph characteristics based on energy and extension were compared to that of the control dough in all cases. Extensograph analysis of control, and BCPC, GSPC and PSPC enriched wheat dough samples were carried out as a function of dough resting time $(45,90$ or $135 \mathrm{~min})$ and the results were shown in Table 3. Compared to the controls, BCPC and GCPC enriched wheat flour doughs were more resistant to extension, whereas opposite results were 
obtained for PSPC samples. In most cases, the extension values of BCPC and GCPC samples were either lower than the corresponding controls or the changes were not statistically significant. Consequently, PSPC dough samples were relatively comparable to the control samples. Although the trends slightly changed over time, resting time dependence of the results were weak.

Farinograph analysis was carried out to determine the degree of softening and stability of the dough samples as influenced by protein enrichment and the results were reported on Table 4. Firstly, farinographic parameters of control bread were found to be comparable to the data in previous literature (Voicu et al., 2017). Water absorption of the dough samples was found to be statistically similar to the control samples. In addition, the degree of softening was lower in most cases compared to the control sample both at 10 and 12 minutes. Possibly the hardest and most stable bread dough samples were attained by the addition of BCPC. In most cases, farinograph and extensograph analyses indicated that the most significantly different attributes were attained by BCPC inclusion in the flour. PSPC containing flour and dough samples were mostly comparable to the controls, which was coherent with our earlier findings on gluten-free formulations (Coşkun et al., 2020).

Table 4. Farinograph parameters of dough samples prepared from protein-fortified flours. D- BCPC: Dough prepared from black cumin protein concentrate enriched wheat flour; D-GSPC: Dough prepared from grape seed protein concentrate enriched wheat flour; D-PSPC: Dough prepared from pumpkin seed protein concentrate enriched wheat flour. a: 10 minutes after the experiment started; b: 12 minutes after the maximum value was attained. The standard deviation was $<5 \%$ of the sample mean in all cases. One-way ANOVA with post hoc Tukey tests were carried out to compare groups and establish statistical significance $(\mathrm{P}<0.05)$. In all cases, at least three replicates were analyzed.

\begin{tabular}{c|ccccc}
\hline Samples & $\begin{array}{c}\text { Water absorption } \\
(\%)\end{array}$ & $\begin{array}{c}\text { Development time } \\
(\mathrm{min})\end{array}$ & $\begin{array}{c}\text { Stability time } \\
(\mathrm{min})\end{array}$ & $\begin{array}{c}\text { Degree of softening } \\
(\mathrm{FU})^{\mathrm{a}}\end{array}$ & $\begin{array}{c}\text { Degree of softening } \\
(\mathrm{FU})\end{array}$ \\
\hline Control & 57.2 & 1.5 & 3 & 60 & 69 \\
D-BCPC & 57.8 & 2 & 7.2 & 42 & 58 \\
D-GSPC & 56.8 & 1.7 & 2.5 & 50 & 76 \\
D-PSPC & 57.6 & 1.5 & 3.4 & 48 & 66 \\
\hline
\end{tabular}

Table 5. Color parameters for baked bread crumb. C-BCPC; Crumb of black cumin protein concentrate enriched bread, C-GSPC: Crumb of grape seed protein concentrate enriched bread, C-PSPC: Crumb of pumpkin seed protein concentrate enriched bread. One-way ANOVA with post hoc Tukey tests were carried out to compare groups and establish statistical significance $(\mathrm{P}<0.05)$. In all cases, at least three replicates were analyzed.

\begin{tabular}{c|ccc}
\hline Samples & $\mathrm{L}^{*}$ & $\mathrm{a}^{*}$ & $\mathrm{~b}^{*}$ \\
\hline Control & $55.6 \pm 0.9^{\mathrm{c}}$ & $2.6 \pm 0.5^{\mathrm{ab}}$ & $24.09 \pm 0.1^{\mathrm{b}}$ \\
C-BCPC & $3.01 \pm 1^{\mathrm{a}}$ & $2.09 \pm 0.1^{\mathrm{a}}$ & $8.95 \pm 0.1^{\mathrm{a}}$ \\
C-GSPC & $32.01 \pm 0.9^{\mathrm{b}}$ & $8.03 \pm 0.4^{\mathrm{b}}$ & $13.65 \pm 0.5^{\mathrm{a}}$ \\
C-PSPC & $55.75 \pm 0.2^{\mathrm{c}}$ & $2.01 \pm 0.5^{\mathrm{a}}$ & $23.45 \pm 2^{\mathrm{b}}$ \\
\hline
\end{tabular}

\section{Analysis of Bread Characteristics}

\section{Texture Profile Analysis}

Texture profile analysis including firmness and springiness attributes of baked bread products prepared from control flour and protein enriched wheat flours were shown in Figure 1. Springiness values of all samples were comparable to that of control sample. In terms of firmness, however, BC samples were distinctly different from the other samples and controls. Once again, water holding capacity of the potentially glycosylated BCPC (Coşkun et al., 2019) and its resistance to extension in dough could have imparted a firmer structure. In addition to water holding capabilities, water soluble polysaccharides from black cumin were shown to demonstrate surface activity possibly due to the presence of proteins in the samples, although the structural attributes were not fully elucidated (Trigui et al., 2018). Previously it was also found out that BC enriched gluten-free bread had lower volume compared to the GS and PS samples, which is coherent with the current observations (Coşkun et al., 2020). In gluten-free formulations, current protein concentrates significantly increased the firmness of the crumb with the exception of PSPC samples, while further water inclusion lead to corrected firmness values (Coşkun et al., 2020).

\section{Visual Characteristics}

Images of baked bread products prepared from control flour, BCPC, GSPC or PSPC enriched wheat flours were shown in Figure 2 as a function of fermentation duration at constant fermentation temperature $\left(35^{\circ} \mathrm{C}\right)$ and relative humidity (90\% RH).

Morphologically, the surface score of BCPC sample was not properly visible after a $90 \mathrm{~min}$ fermentation process. According to the extensograph data, BCPC yielded higher resistance to dough mixing and demonstrated lower extensibility. As fermentation duration increased, the fermentation stability of the BCPC bread was found to be low and geometric deformation was clearly obvious to the naked eye. On the contrary, less resistant GSPC and the least resistant PSPC samples yielded comparable geometries as the control bread.

Color Analysis

Color analysis of baked bread products prepared from control sample, BCPC, GSPC and PSPC enriched wheat flours were shown in Table 5. For almost all color parameters, PSPC sample was similar to the control sample and was hardly distinguishable from the control sample to the naked eye (Figure 2). 

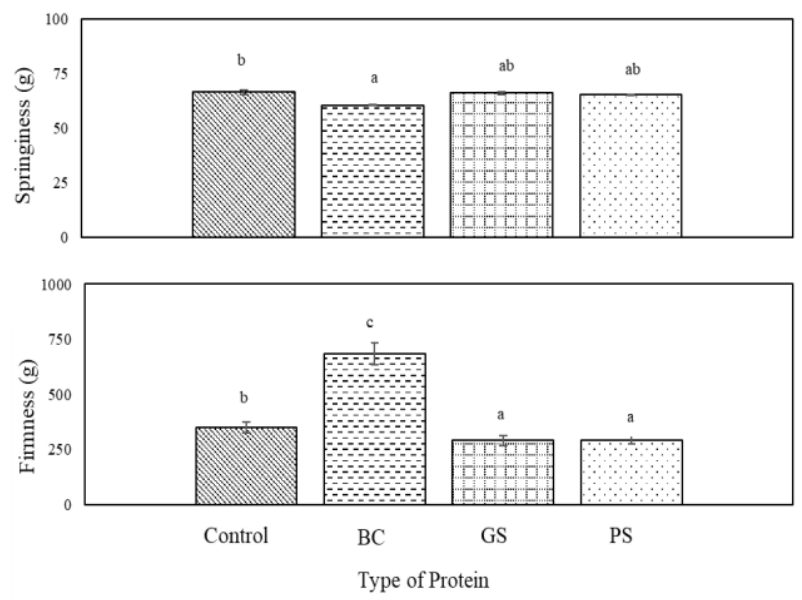

Figure 1. Textural parameters of protein-fortified bread based on the protein concentrate utilized.

BC; black cumin protein concentrate enriched bread, GS: grape seed protein concentrate enriched bread, PS: pumpkin seed protein concentrate enriched bread. A: Springiness (\%), B: Firmness (g).
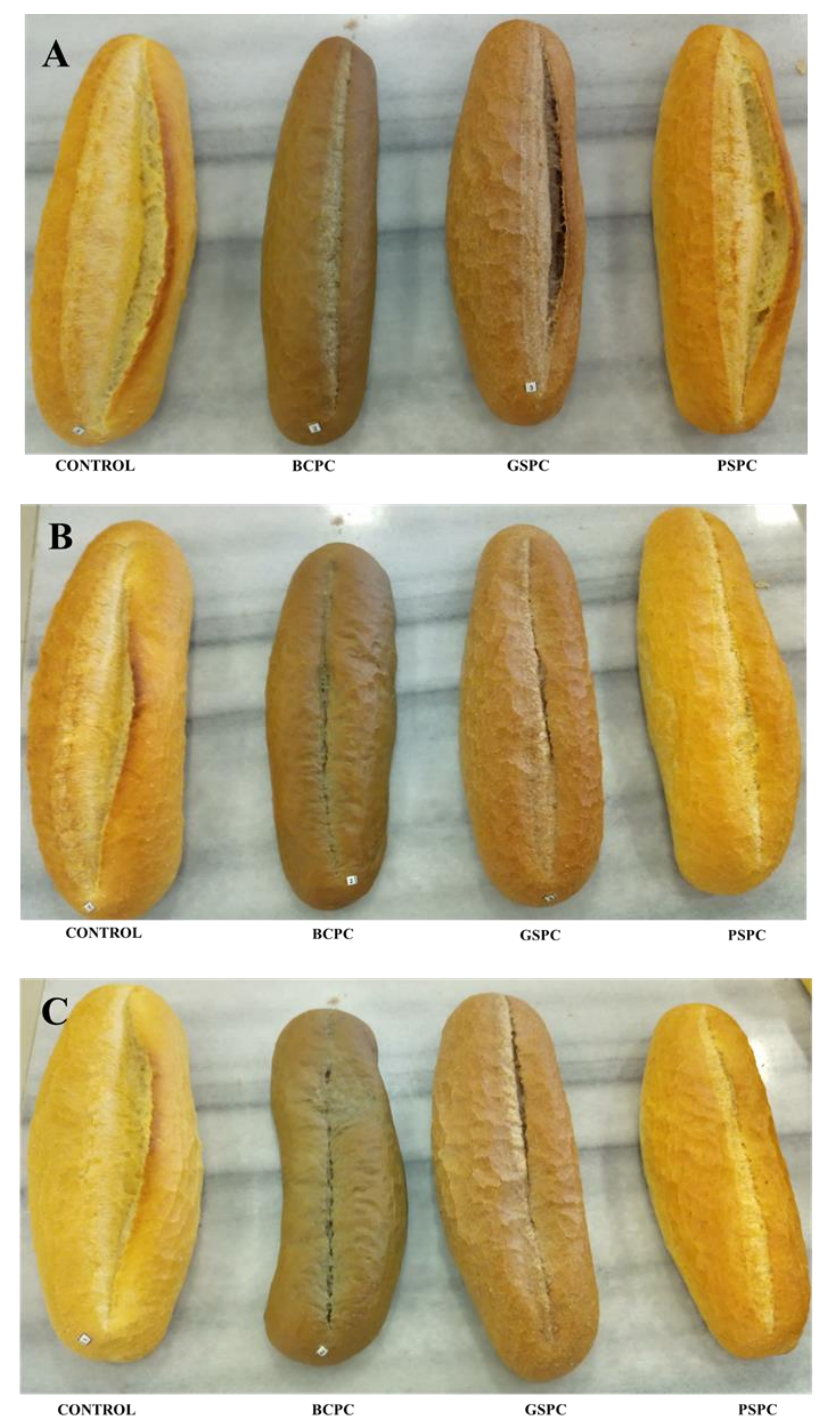

Figure 2. Morphological properties of bread with different fermentation times after baking.

Duration of fermentation; A: 80, B: 110, or C: $140 \mathrm{~min}$.
Due to the natural colors of black cumin and grape seed, their corresponding protein concentrates could be expected to influence the lightness and redness attributes, respectively. These findings were coherent with the expectations, while the other attributes were also significantly affected for both samples. No extra effort was made to remove the color from these concentrates, since natural color should be acceptable to the consumers. This statement will only hold true when the other quality attributes are acceptable. Consequently, while color might not be the sole defining factor, PSPC bread with comparable physical characteristics are more likely to be acceptable to consumers compared to BCPC and GSPC bread.

As indicated in the earlier sections, since the protein: carbohydrate ratio is fairly high in the pumpkin seed, the extent of carbohydrate impurities and water-soluble polysaccharides are lower in the AE-IP protein concentrates. Consequently, the chief attributes of the baked samples such as springiness and firmness were only slightly altered in the PSPC supplemented bread. Furthermore, when the interactions between the added protein and gluten and/or starch granules are relatively weak, seed protein supplementation could enhance protein content while minimally affecting the other physicochemical attributes. The attributes of the final bread samples were highly dependent on purity level and composition of protein concentrates as well as the fermentation duration.

\section{Conclusions}

Supplementation of wheat flour with black cumin, grape seed and pumpkin seed protein concentrates produced dough with satisfactory rheological properties. However, enriched bread, besides PSPC enriched bread had lower volumes, higher firmness and darker color attributes, whereas firmness had a clear bearing on the final attributes of the baked bread samples. The interactions between gluten or starch with seed proteins were relatively weak, which in turn did not significantly affect textural attributes with the exception of black cumin protein addition.

Current seed protein concentrates were conveniently utilized in both gluten-free and gluten-bearing bread formulations in order to valorize cold press technology byproduct streams to generate both nutritionally and technically desirable attributes. The current protein manufacture processes were based on food grade operations and can be adapted to both artisanal and industrial bread manufacture processes leading to sustainability in the utilization of seed-based ingredients. The findings could be applicable to various by-product streams and seed ingredients that contain significant amounts of proteins.

\section{Acknowledgements}

The authors would like to also express their gratitude to Polen Foods (İstanbul, Turkey) for their support in bread making experiments and Neva Foods (İstanbul, Turkey) for the donation of cold press cakes. This study was supported by a grant from TÜBİTAK 3501 Program (Project No. 115O569; 2015-2017; TÜBİTAK). 


\section{References}

AACCI, 2000a. Approved methods of the AACCI (10th Ed.). Method 54.10, St. Paul, MN, USA.

AACCI, 2000b. Approved methods of the AACCI (10th Ed.). Method 54.21, St. Paul, MN, USA.

AOAC, 2003. Official methods of analysis of AOAC International (17th ed.). Gaithersburg, MD, USA: Association of Official Analytical Chemists Inc. (Revision 2).

Baydar H. 2009. Science and technology of medicinal and aromatic plants, $3^{\text {rd }}$ Ed. Süleyman Demirel University, Faculty of Agriculture, Publication No. 51, Turkey.

Baytop T. 1999. Treatment with plants in Turkey. Past and present, $2^{\text {nd }}$ Ed. Nobel Tip kitapevleri, Turkey.

Boye JI, Aksay S, Roufik S, Ribereau S, Mondor M, Farnworth E, Rajamohamed SH. 2010. Comparison of the functional properties of pea, chickpea and lentil protein concentrates processed using ultrafiltration and isoelectric precipitation techniques. Food Research International, 43(2): 537-546.

Bucko S, Katona J, Popovic L, Vastag Z, Petrovic L, VucinicVasic M. 2015. Investigation on solubility, interfacial and emulsifying properties of pumpkin (Cucurbita pepo) seed protein isolate. LWT - Food Science and Technology, 64: 609-615.

Coşkun Ö, Çakır B, Vahapoğlu B, Gülseren İ. 2019. Influence of extraction conditions on structural and functional characteristics of black cumin protein concentrates and ACEinhibition in their hydrolyzates. Journal of Food Measurement and Characterization, 13(3): 2328-38.

Coşkun Ö, Gülseren İ. 2020. Aqueous extraction and functionality of protein concentrates manufactured from cold press meals of pumpkin, pomegranate, and grape seeds. Nutrire, 45: 1-12.

Coşkun Ö, Pehlivanoğlu H, Gülseren İ. 2020. Pilot scale assessment for seed protein enrichment of gluten-free breads at varying water content levels and after protein modification treatments. Journal of Food Processing and Preservation, e14512.

Delcour JA, Hoseney C. 2010. Principles of cereal science and technology, AACC International, 3rd Ed., USA.

Drozłowska E, Łopusiewicz Ł, Mężyńska M, Bartkowiak A. 2020. Valorization of flaxseed oil cake residual from coldpress oil production as a material for preparation of spraydried functional powders for food applications as emulsion stabilizers. Biomolecules, 10 (1): 153.

El-Soukkary FAH. 2001. Evaluation of pumpkin seed products for bread fortification. Plant Foods for Human Nutrition, 56: 365-384.

Fantozzi P. 1981. Grape seed: A potential source of protein. Journal of American Oil Chemists' Society, 58 (12): 1027 31.

FAOSTAT, 2011. Agricultural production domain online. Rome, Italy: Food and Agricultural Organization of the United Nations.

ICC, 1995. The Standard Methods of the ICC, ICC Standard No. 107/1, Vienna, Austria.

ICC, 2000. The Standard Methods of the ICC, ICC Standard No. 137/1, Vienna, Austria.
ICC, 2018. The Standard Methods of the ICC, ICC Standard No. 1161 , Vienna, Austria.

Jafari M, Koocheki A, Milani E. 2017. Physicochemical and sensory properties of extruded sorghum-wheat composite bread. Journal of Food Measurement and Characterization, 12(1): 370-377.

Kamel BS, Dawson H, Kakuda Y. 1985. Characteristics and composition of melon and grape seed oils and cakes. Journal of American Oil Chemists' Society, 62(5): 881-883.

Kaushik R, Kumar N, Sihag MK, Ray A. 2015. Isolation, characterization of wheat gluten and its regeneration properties. Journal of Food Science and Technology, 52(9): 5930-37.

Nergiz C, Ötleş S. 1993. Chemical composition of Nigella sativa L. seeds. Food Chemistry, 48 (3): 259-261.

Paulik S, Yu WW, Flanagan B, Gilbert RG, Jekle M, Becker T. 2019. Characterizing the impact of starch and gluten-induced alterations on gelatinization behavior of physically modified model dough. Food Chemistry, 301: 125276.

Perten Instruments 1995. Fungal Falling Number, method description - enclosure 2, Sweden.

Quanhong L, Caili F. 2005. Application of response surface methodology for extraction optimization of germinant pumpkin seeds protein. Food Chemistry, 92: 701-706.

Samant SK, Rege DV. 1989. Carbohydrate composition of some cucurbit seeds. Journal of Food Composition and Analysis, 2(2): 149-156.

Singh B, Singh N. 2006. Physico-chemical, water and oil absorption and thermal properties of gluten isolated from different Indian wheat cultivars. Journal of Food Science and Technology, 43(3): 251-255.

Stelten S, Dekker IM, Ronday AE, Thijs A, Boelsma E, Peppelenbos H, de van der Schueren MA. 2014. PP208-SUN: Protein-enriched bread and drinking yoghurt and their effect on protein intake in acutely hospitalized older adults; a randomized controlled trial. Clinical Nutrition, 33: S97-S98.

Storck CR, da Rosa Zavareze E, Gularte MA, Elias MC, Rosell CM, Dias ARG. 2013. Protein enrichment and its effects on gluten-free bread characteristics. LWT - Food Science and Technology, 53 (1): 346-354.

Trigui I, Yaich H, Sila A, Cheikh-Rouhou S, Bougatef A, Blecker C, Attia H, Ayadia MA. 2018. Physicochemical properties of water-soluble polysaccharides from black cumin seeds. International Journal of Biological Macromolecules, 117: 937-946.

Voicu G, Constantin G, Ipate G, Tudor P. 2017. Farinographic parameter variation of doughs from wheat flour with amount of water added. In Proceedings of the International Scientific Conference, Latvia University of Agriculture.

Zaidel DA, Chin NL, Yusof YA. 2010. A review on rheological properties and measurements of dough and gluten. Journal of Applied Science, 10(20): 2478-90.

Ziobro R, Witcak T, Juszczak L, Korus J. 2013. Supplementation of gluten-free bread with non-gluten proteins. Effect on dough rheological properties and bread characteristic. Food Hydrocolloids, 32: 213-220. 